\title{
ELASTASE ACTIVITY INHIBITION BY THE MOST ACTIVE FRACTION OF STAR FRUIT (AVERRHOA CARAMBOLA L.) LEAVES FROM THREE WEST JAVA REGIONS
}

\author{
SITI MARDHIYAH, BERNA ELYA*, ARIKADIA NOVIANI \\ Department of Pharmacognosy and Phytochemistry, Faculty of Pharmacy, Universitas Indonesia, Depok, Indonesia. \\ Email: berna.elya@farmasi.ui.ac.id
}

Received: 23 September 2019, Revised and Accepted: 23 December 2019

\section{ABSTRACT}

Objective: Premature skin aging is caused by increased elastase proteolytic activity, which causes elastin breakdown and disorganization in connective tissue, reducing elasticity and flexibility, and wrinkling skin. Natural compounds in plants, especially polyphenols, inhibit elastase proteolytic activity and prevent premature skin aging. Star fruit (Averrhoa carambola L.) leaves contain many polyphenols with antioxidant, anti-inflammatory, hypoglycemic, and antimicrobial activities. However, no studies have shown that $A$. carambola leaves inhibit elastase proteolytic activity.

Methods: This study tested the inhibition of elastase proteolytic activity by the water fractions (WF), ethyl acetate fractions, and n-hexane fractions of $A$. carambola leaves from the Depok, Sukabumi, and Subang regions of West Java. Each fraction was tested using a microplate reader, and the total phenolic and flavonoid content was determined for the most active fraction.

Results: The WF of the $A$. carambola leaves from Depok was the most active fraction, with a half-maximal inhibitory concentration of $160.36 \mu \mathrm{g} / \mathrm{mL}$. The total phenolic and flavonoid content in the WF was $115.68 \mathrm{mg}$ gallic acid equivalent/g extract and $9.15 \mathrm{mg}$ quercetin equivalent/g extract, respectively.

Conclusion: The WF of $A$. carambola leaves is a natural material that may inhibit elastase proteolytic activity and prevents premature skin aging.

Keywords: Premature skin aging, Elastase, Elastin, Averrhoa carambola L.'s leaves.

(C) 2020 The Authors. Published by Innovare Academic Sciences Pvt Ltd. This is an open access article under the CC BY license (http://creativecommons. org/licenses/by/4. 0/) DOI: http://dx.doi.org/10.22159/ijap.2020.v12s1.FF020

\section{INTRODUCTION}

Skin aging is a multisystem, degenerative process involving the skin and its supporting systems [1]. It is influenced by both intrinsic and extrinsic factors. Intrinsic skin aging, or natural aging, is due to factors in the body that cause changes in skin elasticity, while extrinsic skin aging, or photoaging, is caused by environmental factors, especially ultraviolet (UV) radiation that induces free radicals to cause skin aging [2]. Elastin is an extracellular matrix protein that provides resistance and elasticity to tissues and organs. One enzyme that significantly affects premature skin aging is elastase [3]. Increased or excessive elastase proteolytic activity can increase elastin breakdown and disorganization, which leads to decreased skin elasticity and flexibility, resulting in prematurely aging skin [4].

Natural compounds found in plants can inhibit elastase proteolytic activity and may be helpful in overcoming premature skin aging [5]. Previous studies have reported that several polyphenols, such as epigallocatechin gallate, catechins, gallic acid, quercetin, and kaempferol, are effective in preventing and treating skin aging [6,7]. Polyphenols are a large group of chemical compounds, synthesized by plants, with antioxidant and anti-inflammatory activities. They protect the skin against oxidative stress and inhibit elastase proteolytic activity $[8,9]$.

One polyphenol-containing plant with the potential to prevent premature skin aging is the star fruit (Averrhoa carambola L.). A. carambola originates from Asia and is widespread in tropical regions, including Indonesia. There are several varieties of $A$. carambola found in Indonesia, such as the Dewi variety originating from Depok City (known as "star fruit city"), which has been confirmed as a superior variety under the name Dewi Murni (Decree of the Minister of Agriculture No. $717 /$ Kpts/Tp.240/8/98).
A. carambola provides many benefits. While the most widely used part is the fruit, the leaves are used in traditional medicines as appetite enhancers, laxatives, and fever reducers, anti-inflammatories, etc. $[10,11]$. The leaves also have antioxidant, anti-inflammatory, hypoglycemic, antimicrobial, and antihelmintic activities $[10,12,13]$. One study showed that the total phenolic and flavonoid content in A. carambola leaves is 112 -mg gallic acid equivalent (GAE) per gram of extract and $18.18 \mathrm{mg}$ quercetin equivalent (QE) per gram of extract, respectively [11]. The leaves are easily obtainable and abundant compared to other parts of the plant, guaranteeing raw material sustainability, and increasing the leaves' economic value [14].

However, no studies have reported whether the water fractions (WF), ethyl acetate fractions (EAF), and n-hexane fractions (NHF) of A. carambola leaves can inhibit elastase proteolytic activity to prevent and overcome skin aging. Therefore, this study aimed to examine the inhibition of elastase proteolytic activity by the most active fraction of A. carambola leaves from three different regions of West Java, Indonesia, Depok, Sukabumi, and Subang.

\section{MATERIALS AND METHODS}

\section{Materials}

A. carambola leaves from Depok, Sukabumi, and Subang were obtained from the Research Institute of Herbs and Medicinal Plants (Balitro, Bogor, Indonesia) and identified by a botanist at the Center for Plant Conservation Botanical Gardens, Indonesian Institute of Sciences (LIPI, Bogor, Indonesia). Quercetin (Sigma-Aldrich, St. Louis, MO, USA) was used as a positive control to test the inhibitory activity of A. carambola leaves and determine the total flavonoid content, while gallic acid (Sigma-Aldrich, Q4951) was used as a standard to determine the total phenolic content (TPC). Porcine pancreatic elastase (PPE; E1250), $\mathrm{N}$-succinyl-Ala-Ala-Ala- $p$-nitroanilide (SANA; S4760), and Trizma base 
(2-amino-2-hydroxymethyl-propane-1,3-diol) were obtained from Sigma-Aldrich. All extraction and fractionation solvents (distilled water, ethyl acetate, and n-hexane) were obtained from Brataco, Indonesia. All reagents for determining the total phenolic and flavonoid content and for phytochemical screening were obtained from Merck, Germany.

\section{Preparation of materials}

A. carambola leaves were powdered, using a grinding machine or blender, and then macroscopically and microscopically identified.

\section{Extraction}

A. carambola leaf extract was obtained by maceration using $70 \%$ ethanol as a solvent. Briefly, the dried A. carambola leaf powder was put in a container, which was then filled with $70 \%$ ethanol in a powder (g):solvent $(\mathrm{mL})$ ratio of $1: 10$. The powder was soaked for $6 \mathrm{~h}$, with stirring, and then allowed to stand for $18 \mathrm{~h}$. Then, the macerate was separated by precipitation and filtration and finally evaporated in a rotary vacuum evaporator and water bath at $50{ }^{\circ} \mathrm{C}$ until a crude extract was obtained.

The A. carambola leaf crude extract yield from the maceration was calculated as

$$
\text { Yield }(\%)=\frac{\text { Crude extract weight }}{\text { Sample weight }} \times 100 \%
$$

\section{Fractionation}

Fractionation (liquid-liquid partition) was carried out using n-hexane (nonpolar), ethyl acetate (semipolar), and distilled water (polar) to separate substances according to polarity. Warm, distilled water was added for a crude extract $(\mathrm{g})$ :solvent $(\mathrm{mL})$ ratio of 1:10. Then, $\mathrm{n}$-hexane was added for partitioning; the mixture was shaken thrice for 5 min each time in a separating funnel, and it was allowed to stand for $3 \mathrm{~h}$ until two layers of water (bottom) and n-hexane (top) were formed. The two layers were separated; this process was carried out thrice until no more compounds could be separated. The n-hexane layers were combined, forming the NHF, while the water layers were partitioned further, as before, using ethyl acetate. The semipolar fraction of the residual results of ethyl acetate partitioning was obtained by concentration in a rotary vacuum evaporator at a speed of $100 \mathrm{rpm}$ at $40^{\circ} \mathrm{C}$.

Elastase proteolytic activity inhibition test on the positive control Elastase proteolytic activity inhibition was evaluated in vitro using a PPE enzyme inhibitory assay, as described by Wittenauer et al. [3] and Desmiyati et al. [15], with some modifications. PPE inhibition was determined using SANA as a substrate.

The assay consisted of a blank (substrate and enzyme), a blank control (substrate and buffer without enzyme), the sample (sample, enzyme, and substrate), and a sample control (sample and substrate without enzyme). The reaction mixture contained $100 \mathrm{mM}$ Tris- $\mathrm{HCl}$ buffer (pH 8), $0.8 \mathrm{U} / \mathrm{mL}$ of PPE, $2.9 \mathrm{mM}$ SANA (Table 1). The reaction mixture was pre-incubated for $20 \mathrm{~min}$ at $25^{\circ} \mathrm{C}$. Quercetin was used as a positive control.

The test was carried out by making quercetin solutions with concentrations of $1000,1500,2000,2500$, and $3000 \mu \mathrm{g} / \mathrm{mL}$ (the final concentrations of quercetin in the reaction were 100, 150, 200, 250, and $300 \mu \mathrm{g} / \mathrm{mL}$ ). The reaction product was monitored by measuring absorbance at a wavelength of $401 \mathrm{~nm}$ using a VersaMax enzyme-linked immunosorbent assay (ELISA) microplate reader (X, USA).

Elastase proteolytic activity inhibition was expressed as the percentage inhibition relative to the corresponding control. The percentage inhibition was calculated as

$$
\text { Percentage inhibition }(\%)=\frac{(\mathrm{C}-\mathrm{S})}{\mathrm{C}} \times 100 \%
$$

(or)

$$
\left(1-\frac{S}{C}\right) \times 100 \%
$$

where $\mathrm{C}$ is the absorbance of the blank (blank-blank control) or enzyme activity without an inhibitor, and $\mathrm{S}$ is the absorbance of the sample (sample-sample control) or enzyme activity in the presence of an inhibitor.

The half-maximal inhibitory concentration $\left(\mathrm{IC}_{50}\right)$ of the sample that inhibited $50 \%$ of elastase proteolytic activity under test conditions was obtained by making a linear regression equation with the sample concentration as the $\mathrm{X}$-axis and the percentage inhibition as the $\mathrm{Y}$-axis to produce the equation $\mathrm{y}=\mathrm{a}+\mathrm{bx}$.

$$
\mathrm{IC}_{50}=\frac{50-\mathrm{a}}{\mathrm{b}}
$$

\section{Elastase proteolytic activity inhibition test on the sample}

The percentage inhibition of the WF, EAF, and NHF of the A. carambola leaves from Depok, Sukabumi, and Subang was screened to find out the most active fraction with the greatest potential for inhibiting elastase proteolytic activity. The final sample concentration used for testing was $200 \mu \mathrm{g} / \mathrm{mL}$.

\section{Phytochemical screening}

Phytochemical screening includes the identification of flavonoids, alkaloids, tannins, terpenoids, saponins, glycosides, and anthraquinones. Phytochemical screening was performed to determine the phytochemical compounds contained in the most active fraction. Phytochemical screening for the active fraction was conducted by the qualitative method, as described by the Indonesian Materia Medika (1995) [16] and Harborne [17], using the alkaloid test with Mayer, Dragendorff, and Bouchardat reagents; the flavonoid test with the Shinoda and Wilson Toubock reaction; the tannin test with gelatin, gelatin-salt, and ferrous (III) chloride; the saponin test with honeycomb froth; the terpenoid test with Liebermann-Burchard reagent; and the anthraquinone test with the Borntrager reaction.

\section{Determination of the TPC}

The TPC was determined using the Folin-Ciocalteu method, as given by Singleton et al. [18] and Pratami et al. [19], with some modifications. Briefly, $25 \mu \mathrm{L}$ of the sample or standard solution was mixed with $100 \mu \mathrm{L}$ of 1:4 diluted Folin-Ciocalteu reagent, shaken for $60 \mathrm{~s}$ in a 96-well microplate and incubated for $4 \mathrm{~min}$. Then, $75 \mu \mathrm{L}$ of sodium carbonate solution $(100 \mathrm{~g} / \mathrm{L})$ was added to the mixture and shaken for $60 \mathrm{~s}$. The mixture was incubated at room temperature for $2 \mathrm{~h}$. Absorbance was measured at a wavelength of $765 \mathrm{~nm}$ using a VersaMax ELISA microplate reader.

Before testing the sample, gallic acid was tested as a standard to obtain a linear regression equation to calculate the TPC in the sample. Gallic acid was diluted in six final concentrations: $3.125,6.250,9.375,12.500$, 15.625 , and $18.750 \mu \mathrm{g} / \mathrm{mL}$. The calibration curve of gallic acid with the six final concentrations was monitored by measuring the absorbance using a microplate reader at a wavelength of $765 \mathrm{~nm}$, and the following linear regression equation was calculated using Microsoft Excel:

Table 1: Elastase proteolytic activity inhibition assay composition

\begin{tabular}{lllll}
\hline Reagent & \multicolumn{3}{l}{ Volume $(\boldsymbol{\mu L})$} \\
\cline { 2 - 5 } & $\begin{array}{l}\text { Blank } \\
\text { clank } \\
\text { control }\end{array}$ & $\begin{array}{l}\text { Sample } \\
\text { Demineralized aqua }\end{array}$ & $\begin{array}{l}\text { Sample } \\
\text { control }\end{array}$ \\
\hline Sample & 20 & 20 & - & - \\
Tris-HCl Buffer 100 mM pH 8 & 140 & - & 20 & 20 \\
Elastase Enzyme (0,8 U/mL) & 20 & - & 140 & 160 \\
$N$-succinyl-(Ala) & 20 & 20 & 20 & - \\
3- $p$-nitroanilide 2.9 mM & & & & \\
\hline
\end{tabular}




$$
\mathrm{Y}=0.0471 \mathrm{X}+0.0601 \text { and } \mathrm{R}^{2}=0.9993
$$

where $\mathrm{Y}$ is the yield in GAE (TPC) and $\mathrm{X}$ is the absorbance of gallic acid or the sample.

After that, the TPC in the sample was determined. All experiments were carried out in triplicate.

\section{Determination of the total flavonoid content}

The total flavonoid content was determined according to the methods given in Pharmacopoeia Herbal Indonesia Supplement III [20] using a quercetin comparator. Quercetin was used as a standard to develop calibration curves with different concentrations of 12.5, 25.0, 50.0, 80.0 , and $100.0 \mu \mathrm{g} / \mathrm{mL}$ in $80 \%$ ethanol. To determine the total flavonoid content, a solution of quercetin or active fraction in $0.5 \mathrm{~mL}$ was mixed with $1.5 \mathrm{~mL}$ of ethanol, $0.1 \mathrm{~mL}$ of $10 \% \mathrm{AlCl}_{3}$ solution, $0.1 \mathrm{~mL}$ of $1 \mathrm{M}$ sodium acetate, and $2.8 \mathrm{~mL}$ of distilled water in a test tube. For a sample blank, the sample containing the listed components except $\mathrm{AlCl}_{3}$ was replaced by the same quantity of distilled water. The mixture was shaken and incubated at room temperature for $30 \mathrm{~min}$. Absorbance was measured using a Shimadzu 265 UV-visible spectrophotometer (Shimadzu, Japan) at a wavelength of $430 \mathrm{~nm}$. The total flavonoid content was derived from the calibration curve.

In measuring the total flavonoid content, the net absorption value was plotted against the quercetin standard curve, and then the value of the total flavonoid content was calculated.

\section{Statistical analysis}

Differences in the average percentage inhibition of elastase proteolytic activity were analyzed by analysis of variance. $P<0.05$ was considered statistically significant.

A correlation test was conducted between TPC and percentage inhibition and also between the total flavonoid content and percentage inhibition using Pearson's correlation because the data were distributed normally.

\section{RESULTS}

\section{Extraction}

Table 2 shows the crude extract yield obtained from A. carambola leaves from Depok, Sukabumi, and Subang: 32.22\%, 23.68\%, and 35.28\%, respectively.

\section{Fractionation}

Table 3 shows the yield of the WF, EAF, and NHF of A. carambola leaves from Depok, Sukabumi, and Subang. As shown, the WF, EAF, and NHF

Table 2: Yield of crude extract obtained from leaves of A. carambola from Depok, Sukabumi, and Subang

\begin{tabular}{llll}
\hline $\begin{array}{l}\text { Origin area of } \\
\text { A. carambola }\end{array}$ & $\begin{array}{l}\text { Sample } \\
\text { weight }(\mathrm{g})\end{array}$ & $\begin{array}{l}\text { Crude extract } \\
\text { weight }(\mathrm{g})\end{array}$ & Yield (\%) \\
\hline Depok & 1400 & 451.13 & 32.22 \\
Sukabumi & 700 & 165.79 & 23.68 \\
Subang & 700 & 246.59 & 35.28 \\
\hline
\end{tabular}

A. carambola: Averrhoa carambola yields were highest in samples from Subang, followed by Depok and Sukabumi.

\section{Elastase proteolytic activity inhibition test on the control}

Test results of quercetin inhibition of elastase proteolytic activity are shown in Table 4. Based on the results, the percentage inhibition value was obtained at each quercetin concentration, and the linear regression equation was $\mathrm{y}=0.3038 \mathrm{x}-10.761$. The percentage inhibition was highest $(79.33 \%)$ at a quercetin concentration of $300 \mu \mathrm{g} / \mathrm{mL}$, and the quercetin $\mathrm{IC}_{50}$ was $200.003 \mu \mathrm{g} / \mathrm{mL}$

\section{Elastase proteolytic activity inhibition test on the sample}

The percentage inhibition values of the WF, EAF, and NHF of A. carambola leaves from Depok, Subang, and Sukabumi are depicted in Table 5 and Fig. 1. As shown in Table 5, the percentage inhibition of all three fractions was highest $(64.66 \%, 39.22 \%$, and $18.62 \%$, respectively) for A. carambola leaves from Depok, followed by Subang and Sukabumi. In addition, the WF produced higher percentage inhibition compared to the EAF and NHF obtained from A. carambola leaves from Depok, Subang, and Sukabumi (Table 5). Therefore, the WF of A. carambola leaves from Depok is the most active fraction for inhibiting elastase proteolytic activity.

\section{Phytochemical screening}

Table 6 shows phytochemical screening results for the WF of A. carambola leaves from Depok. The WF of $A$. carambola leaves contained flavonoids, alkaloids, tannins, saponins, glycosides, and terpenoids. The percentage inhibition was highest $(83.82 \%)$ at the highest WF final concentration of $300 \mu \mathrm{g} / \mathrm{mL}$

The higher the sample concentration, the higher the percentage inhibition. Based on these results, linear regression values were calculated, which could be used as $\mathrm{IC}_{50}$ calculations. As mentioned earlier, the quercetin $\mathrm{IC}_{50}$ was $200.003 \mu \mathrm{g} / \mathrm{mL}$. In contrast, the WF $\mathrm{IC}_{50}$ was $160.36 \mu \mathrm{g} / \mathrm{mL}$ (Table 6). These results showed that the WF of $A$. carambola leaves has better inhibitory activity compared to quercetin.

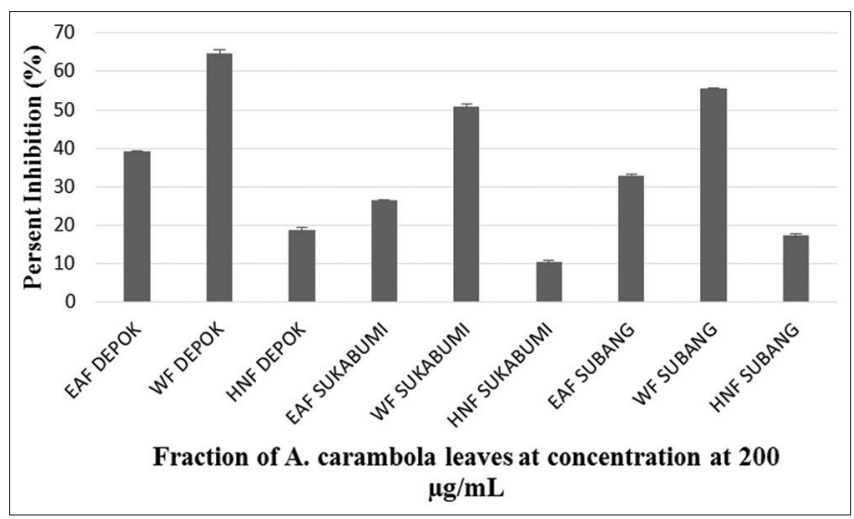

Fig. 1: Percentage inhibition of WF, EAF, and NHF of the leaves of Averrhoa carambola from Depok, Sukabumi, and Subang. WF: Water fraction; EAF: Ethyl acetate fraction; NHF: n-hexane fraction

Table 3: Yield of WF, EAF, and NHF of the leaves of A. carambola from Depok, Subang, and Sukabumi

\begin{tabular}{lllll}
\hline Origin area of A. carambola & Fraction & Weight of crude extract fractionated (g) & Fraction weight (g) & Yield (\%) \\
\hline Depok & Water & 401.13 & 167.34 & 41.72 \\
& Ethyl acetate & 401.13 & 16.83 & 4.195 \\
Subang & n-hexane & 401.13 & 3.25 & 0.81 \\
& Water & 246.59 & 133.18 & 54.01 \\
Sukabumi & Ethyl acetate & 246.59 & 15.24 & 6.18 \\
& n-hexane & 246.59 & 2.62 & 1.06 \\
& Water & 165.79 & 54.52 & 32.88 \\
& Ethyl acetate & 165.79 & 6.30 & 3.88 \\
\hline
\end{tabular}

WF: Water fraction; EAF: Ethyl acetate fraction; NHF: n-hexane fraction; A. carambola: Averrhoa carambola 
Table 4: Percentage inhibition of elastase proteolytic activity by quercetin at different concentrations

\begin{tabular}{llll}
\hline $\begin{array}{l}\text { Final concentration } \\
\text { of quercetin in test } \\
\text { solution }(\boldsymbol{\mu g} / \mathbf{m L})\end{array}$ & $\begin{array}{l}\text { Percentage } \\
\text { inhibition } \\
(\%)\end{array}$ & $\begin{array}{l}\text { Linear regression } \\
\text { equations }\end{array}$ & $\begin{array}{l}\mathrm{IC}_{\mathbf{5 0}} \\
(\boldsymbol{\mu} \mathbf{g} / \mathbf{m L})\end{array}$ \\
\hline 100 & 19.17 & $\mathrm{y}=0.3038 \mathrm{x}-10.761$ & 200.003 \\
150 & 34.38 & $\mathrm{r}=0.999249719$ & \\
200 & 51.15 & & \\
250 & 65.97 & & \\
300 & 79.33 & & \\
\hline
\end{tabular}

Table 5: Percentage inhibition of WF, EAF, and NHF of the leaves of A. carambola from Depok, Subang, and Sukabumi

\begin{tabular}{llll}
\hline Fraction & $\begin{array}{l}\text { Origin } \\
\text { area of } \\
\text { A.carambola }\end{array}$ & $\begin{array}{l}\text { Final concentration } \\
\text { of samples in test } \\
\text { solution }(\boldsymbol{\mu g} / \mathbf{m L})\end{array}$ & $\begin{array}{l}\text { Percentage } \\
\text { inhibition (\%) }\end{array}$ \\
\hline Water & Depok & 200 & 64.66 \\
Ethyl acetate & & 200 & 39.22 \\
n-hexane & & 200 & 18.62 \\
Water & Sukabumi & 200 & 50.84 \\
Ethyl acetate & & 200 & 26.55 \\
n-hexane & & 200 & 10.33 \\
Water & Subang & 200 & 55.53 \\
Ethyl acetate & & 200 & 32.94 \\
n-hexane & & 200 & 17.32 \\
\hline
\end{tabular}

WF: Water fraction; EAF: Ethyl acetate fraction; NHF: n-hexane fraction; A. carambola: Averrhoa carambola

Table 6: Percentage inhibition and $\mathrm{IC}_{50}$ for elastase proteolytic activity by WF (the most active fraction) of the leaves of A. carambola from Depok

\begin{tabular}{llll}
\hline $\begin{array}{l}\text { Final concentration } \\
\text { of Depok WF in test } \\
\text { solution }(\boldsymbol{\mu g} / \mathbf{m L})\end{array}$ & $\begin{array}{l}\text { Percentage } \\
\text { inhibition } \\
\mathbf{( \% )}\end{array}$ & $\begin{array}{l}\text { Linear regression } \\
\text { equations }\end{array}$ & $\begin{array}{l}\mathbf{I C}_{\mathbf{5 0}} \\
(\boldsymbol{\mu g} / \mathbf{m L})\end{array}$ \\
\hline 100 & 35.86 & $\mathrm{y}=0.2456 \mathrm{x}+10.615$ & 160.36 \\
150 & 45.52 & $\mathrm{r}=0.99798978$ & \\
200 & 61.09 & & \\
250 & 72.42 & & \\
300 & 83.82 & & \\
\hline
\end{tabular}

WF: Water fraction, $\mathrm{IC}_{50}$ : Half-maximal inhibitory concentration,

A. carambola: Averrhoa carambola

Table 7 shows test results for the presence of various phytochemical compounds in the WF of A. carambola leaves from Depok, Subang, and Sukabumi. As shown, the WFs from all three regions were positive for all compounds except anthraquinone.

\section{TPC in the most active fraction}

The TPC values of the WF of A. carambola leaves from Depok, Subang, and Sukabumi are given in Table 8. The TPC was highest (115.68 mg $\mathrm{GAE} / \mathrm{g}$ fraction) for the WF of the leaves of A. carambola from Depok.

Based on a statistical analysis of the relationship between the TPC and elastase proteolytic activity inhibition, data were normally distributed, with $\mathrm{p}=0.940$ ( $\mathrm{p}>0.05)$. Based on Pearson's correlation, $\mathrm{p}=0.034$ $(p<0.05)$ showed that the TPC significantly affects elastase proteolytic activity inhibition. The correlation value was 0.999 ( $\mathrm{r}$ approaching 1 ), indicating that the TPC is positively correlated with elastase proteolytic activity inhibition.

\section{Total flavonoid content in the most active fraction}

The standard curve for pure quercetin absorbance versus concentration was linear $(y=0.082 x-0.006 ; r=0.9996)$, which was used to estimate the total flavonoid content in the WFs of A. carambola leaves from Depok, Subang, and Sukabumi (Table 9). The total flavonoid content was highest (9.15 mg QE/g fraction) for the WF of $A$. carambola leaves from Depok, while it was not significantly different for Subang and Sukabumi ( 8.68 vs. $8.38 \mathrm{mg} \mathrm{QE} / \mathrm{g}$ fraction).

Based on a statistical analysis of the relationship between the total flavonoid content and elastase proteolytic activity inhibition, data were distributed normally, with $\mathrm{p}=0.758(\mathrm{p}>0.05)$. Based on Pearson's correlation, $\mathrm{p}=0.036(\mathrm{p}<0.05)$ showed that the total flavonoid content significantly affects elastase proteolytic activity inhibition. The correlation value was 0.998 ( $\mathrm{r}$ approaching 1 ), indicating that the total flavonoid content is positively correlated with elastase proteolytic activity inhibition.

\section{DISCUSSION}

\section{Extraction}

Maceration is an extraction process that involves soaking a sample in a solvent at room temperature and shaking or stirring several times until the required macerate concentration is obtained in a balanced state [21]. Maceration was selected in this study because, in addition to being simple, it uses solvents, which break down the cell wall and cell membrane because of the pressure difference between the inside and the outside of the cell. Secondary metabolites in the cytoplasm dissolve in the solvents, making compound extraction efficient [22]. In addition, maceration is performed at room temperature, minimizing damage to, or degradation of, secondary metabolites. Ethanol was selected because it met the criteria of a good solvent that is cheap, easy to obtain, physically and chemically stable, neutral, non-flammable, and selective, i.e., it attracts only the desired nutritious substances and does not affect the active substance. Ethanol has a good ability to attract polyphenols and flavonoids found in A. carambola leaves, because, in general, flavonoids bind to sugars to form glycosides. Therefore, flavonoids dissolve more easily in polar solvents, such as ethanol, methanol, and butanol [23]. Nabilah et al. reported that $70 \%$ ethanol gives the highest yield $(43.04 \%)$ compared to $50 \%$ ethanol $(36.27 \%)$ and $96 \%$ ethanol (22.55\%) [24]. In addition, $70 \%$ of ethanol produces the highest phenol and flavonoid values [25]

\section{Fractionation}

Fractionation is a procedure that separates compounds into smaller fractions based on their polarity. The method involves using two solvents that do not mix. N-hexane has a dielectric constant of 2.2 and attracts non-polar compounds such as chlorophyll, fat, triterpenoids, and steroids. Ethyl acetate has a dielectric constant of 6.02 and attracts semi-polar compounds, such as isoflavones, flavones, flavonoids, and flavonols. Water has a highly polar dielectric constant of 80.4 and is used to attract polar compounds, such as alkaloids, tannins, saponins, and flavonoids.

Elastase proteolytic activity inhibition test on the positive control Quercetin is a flavonoid compound, widely available in various plants, which inhibits elastase activity. The resulting quercetin $\mathrm{IC}_{50}$ of $200.003 \mu \mathrm{g} / \mathrm{mL}$ was slightly different compared to a previous study $(221.69 \mu \mathrm{g} / \mathrm{mL})[26]$. This was due to different test conditions.

\section{Elastase proteolytic activity inhibition test on the sample} Differences in A. carambola growth sites can affect elastase proteolytic activity inhibition because of the effects of environmental factors, such as differences in site height, humidity, and rainfall, which affect the chemical content of a plant. This, in turn, affects its inhibitory activity [27].

Phenolic compounds, such as epicatechin, catechin, epigallocatechin, and gallic acid, and flavonoids, such as quercetin, kaempferol, and myricetin, can significantly inhibit elastase proteolytic activity $[3,28]$. The WF of $A$. carambola leaves contains flavonoids, alkaloids, tannin, saponins, glycosides, and terpenoids. In addition, Chen et al. [8] reported that the polar fraction of $A$. carambola leaves contains several polyphenols, such as gallic acid, proanthocyanidin, and catechins. The flavonoids in A. carambola leaves include flavonoid 0 -glycosides (e.g., quercetin-3-0- $\beta$-D glycosides and routine). Other 
Table 7: Phytochemical screening result of the most active fraction of $A$. carambola leaves

\begin{tabular}{llll}
\hline \multirow{2}{*}{ Phytochemical compound } & \multicolumn{3}{l}{ Phytochemical screening result } \\
\cline { 2 - 4 } & Depok & Subang & Sukabumi \\
\hline Flavonoid & + & + & + \\
Alkaloid & + & + & + \\
Tannin & + & + & + \\
Saponin & + & + & + \\
Terpenoid & + & + & + \\
Glikosida & + & + & + \\
Antrakuinon & - & - & - \\
\hline
\end{tabular}

A. carambola: Averrhoa carambola

Table 8: TPC in WF of leaves of $A$. carambola from Depok, Subang, and Sukabumi, as the most active fraction

\begin{tabular}{ll}
\hline Sample & TPC (mg GAE/g fraction) \\
\hline WF of A. carambola L.'s leaves Depok & 115.68 \\
WF of A. carambola L.'s leaves Subang & 94.59 \\
WF of A. carambola L.'s leaves & 81.28 \\
Sukabumi &
\end{tabular}

Sukabumi

TPC: Total phenol content; WF: Water fraction; GAE: Gallic acid equivalent; A. carambola: Averrhoa carambola

Table 9: Total flavonoid content in WF of leaves of $A$. carambola from Depok, Subang, and Sukabumi, as the most active fraction

\begin{tabular}{ll}
\hline Sample & $\begin{array}{l}\text { Total flavonoid content } \\
\text { (mg QE/g fraction) }\end{array}$ \\
\hline WF of A. carambola L.'s leaves Depok & 9.15 \\
WF of A. carambola L.'s leaves Subang & 8.68 \\
WF of A. carambola L.'s leaves & 8.38 \\
Sukabumi &
\end{tabular}

WF: Water fraction; QE: Quercetin equivalent; A. carambola: Averrhoa carambola

components identified in A. carambola leaves include quercetin-3-0$\beta$-D glycosides, quercetin-3-0-rhamnosida, routine, sianidin-3-0- $\beta$-D glycosides, sianidin-3.5-0- $\beta$-D diglucoside, C-glycosides, and flavonoids such as apigenin-6-C- $\beta$-L-fucopyranoside, apigenin-6-C- $(2$ "- $0-\alpha-\mathrm{L}-$ rhamnopyranosyl)- $\beta$-L-fucopyranoside, and 6-C- $\beta$-1-fucopiranoside (also known as caramboflavone) $[12,29,30]$.

Polyphenols inhibit elastase proteolytic activity by forming hydrogen bonds between their hydroxyl group with amino acids in the enzyme, causing a hydrophobic effect that results in a complex or aggregate, insoluble precipitate, which decreases catalytic activity and denatures the enzyme. Polyphenols form hydrogen bonds with amino acids in PPE: Serine, histamine, and aspartate residues known as the catalytic triad [31]. These findings indicate that the WF of $A$. carambola leaves plays a major role in inhibiting elastase proteolytic activity.

\section{Total phenolic and flavonoid content in the most active fraction}

The higher the TPC and total flavonoid content, the higher the elastase proteolytic activity inhibition. This finding is consistent with previous studies indicating that polyphenols, including flavonoids, play an important role in inhibiting elastase proteolytic activity $[3,25]$.

\section{CONCLUSION}

The WF of $A$. carambola leaves from Depok is the most active fraction and has the highest elastase proteolytic activity inhibition, with $\mathrm{IC}_{50}=160.36 \mu \mathrm{g} / \mathrm{mL}$. The total phenolic and flavonoid content is directly proportional to elastase proteolytic activity inhibition. The higher the total phenolic and flavonoid content, the higher the elastase proteolytic activity inhibition. Therefore, the WF of $A$. carambola leaves is a natural material that could inhibit elastase proteolytic activity and prevent premature skin aging.

\section{ACKNOWLEDGMENTS}

This research was supported by Hibah Tugas Akhir Doktor UI 2018 provided by Universitas Indonesia.

\section{CONFLICTS OF INTEREST}

The author has no conflicts of interest to declare.

\section{REFERENCES}

1. Kohl E, Steinbauer J, Landthaler M, Szeimies RM. Skin ageing. J Eur Acad Dermatol Venereol 2011;25:873-84.

2. Gonzaga ER. Role of UV light in photodamage, skin aging, and skin cancer: Importance of photoprotection. Am J Clin Dermatol 2009; 10 Suppl 1:19-24.

3. Wittenauer J, Mäckle S, Sußmann D, Schweiggert-Weisz U, Carle R. Inhibitory effects of polyphenols from grape pomace extract on collagenase and elastase activity. Fitoterapia 2015;101:179-87.

4. Scott DW, Miller WH. Structure and function of the skin. In: Scott DW, Miller WH, editors. Equine Dermatology. Saint Louis: WB Saunders; 2011. p. $1-58$.

5. Garg C, Khurana P, Garg M. Molecular mechanisms of skin photoaging and plant inhibitors. Int J Green Pharm 2017;11:217-32.

6. Masaki H. Role of antioxidants in the skin: Anti-aging effects. J Dermatol Sci 2010;58:85-90.

7. McCullough JL, Kelly KM. Prevention and treatment of skin aging. Ann N Y Acad Sci 2006;1067:323-31.

8. Chen L, Teng H, Xie Z, Cao H, Cheang WS, Skalicka-Woniak K, et al. Modifications of dietary flavonoids towards improved bioactivity: An update on structure-activity relationship. Crit Rev Food Sci Nutr 2018;58:513-27.

9. Quideau S, Deffieux D, Douat-Casassus C, Pouységu L. Plant polyphenols: Chemical properties, biological activities, and synthesis. Angew Chem Int Ed Engl 2011;50:586-621.

10. Moresco HH, Queiroz GS, Pizzolatti MG, Brighente IM. Chemical constituents and evaluation of the toxic and antioxidant activities of Averrhoa carambola leaves. Rev Bras Farmacogn 2012;22:319-24.

11. Khanam Z, Sam KH, Hazerra N, Chua HC, Haq BU. Determination of polyphenolic content, HPLC analyzes and DNA Cleavage activity of Malaysian A. carambola L. fruit extract. J King Saud Univ Sci 2015;27:331-7.

12. Cabrini DA, Moresco HH, Imazu P, da Silva CD, Pietrovski EF, Mendes DA, et al. Analysis of the potential topical anti-inflammatory activity of Averrhoa carambola L. in mice. Evid Based Complement Alternat Med 2011;2011:908059.

13. Ferreira EB, Fernandes LC, Galende SB, Cortez DA, Bazotte RB. Hypoglycemic effect of the hydroalcoholic extract of leaves of Averrhoa carambola L. (Oxalidaceae). Rev Bras Farmacogn 2008;18:339-43.

14. Rahayu M, Susiarti S, Sihontang VBL. A preliminary ethnobotanical study on useful plants by local communities in Bodogol Lowland Forest, Sukabumi, West Java. J Trop Biol Conserv 2012;9:115-25.

15. Desmiyati Y, Winarti W, Nursih AM. Antioxidant and antielastase activity of Kaempferia rotunda and Curcuma zedoaria. Res J Chem Environ 2018;22:95-8.

16. Ministry of Health of the Republic of Indonesia. Materia Medika Indonesia. Vol. 4. Jakarta: Ministry of Health of the Republic of Indonesia; 1995.

17. Harborne J. Phytochemical Methods. New Delhi, India: Springer; 2008.

18. Singleton VL, Rossi JA Jr. Colorimetry of total phenolics with phosphomolybdic-phosphotungstic acid reagents. Am J Enol Vitic 1965;16:144-58

19. Pratami D, Mun'im A, Sundowo A, Sahlan M. Phytochemical profile and antioxidant activity of propolis ethanolic extract from Tetragonula bee. Pharmacogn J 2017;10:128-35.

20. Ministry of Health of the Republic of Indonesia. Directorate General of Pharmaceutical and Medical Devices Development. Suplemen III Farmakope Herbal Indonesia. Jakarta: Ministry of Health of the Republic of Indonesia; 2013.

21. Ministry of Health of the Republic of Indonesia. Common Standard Parameters of Medicinal Plant Extracts. Jakarta: Ministry of Health of the Republic of Indonesia; 2000.

22. Azwanida N. A review on the extraction methods use in medicinal plants, principle, strength and limitation. Med Aromat Plants 2015;4:2167-412.

23. Hanani E. Analisis Fitokimia. Jakarta: EGC; 2014.

24. Nabilah N, Elya B, Djajadisastra J. Lipoxygenase inhibitory assay of 
Averrhoa carambola L. leaves extract. Int J Chemtech Res 2017;10:342-47.

25. Thring TS, Hili P, Naughton DP. Anti-collagenase, anti-elastase and anti-oxidant activities of extracts from 21 plants. BMC Complement Altern Med 2009;9:27.

26. Liyanaarachchi G, Samarasekera J, Mahanama K, Hemalal K. Tyrosinase, elastase, hyaluronidase, inhibitory and antioxidant activity of Sri Lankan medicinal plants for novel cosmeceuticals. Ind Crops Prod 2018;111:597-605.

27. Liu W, Yin D, Li N, Hou X, Wang D, Li D, et al. Influence of environmental factors on the active substance production and antioxidant activity in Potentilla fruticosa $\mathrm{L}$. and its quality assessment. Sci Rep 2016;6:28591.
28. Kanashiro A, Souza JG, Kabeya LM, Azzolini AE, LucisanoValim YM. Elastase release by stimulated neutrophils inhibited by flavonoids: Importance of the catechol group. Z Naturforsch C J Biosci 2007;62:357-61.

29. Araho D, Miyakoshi M, Chou WH, Kambara T, Mizutani KT, Ikeda T. A new flavone cglycoside from the leaves of Avehrroa carambola. Nat Med 2005;59:113-16.

30. Dasgupt P, Chakraborty P, Bala NN. Averrhoa carambola: An update review. Int J Pharm Res Rev 2013;2:58

31. Brás NF, Gonçalves R, Mateus N, Fernandes PA, Ramos MJ, de Freitas V. Inhibition of pancreatic elastase by polyphenolic compounds. J Agric Food Chem 2010;58:10668-76. 